University of New Hampshire

University of New Hampshire Scholars' Repository

Inquiry Journal 2014

Inquiry Journal

Spring 2014

\title{
Searching for Opportunities
}

Sasa Tang

University of New Hampshire - Main Campus

Follow this and additional works at: https://scholars.unh.edu/inquiry_2014

Part of the International and Area Studies Commons

\section{Recommended Citation}

Tang, Sasa, "Searching for Opportunities." (2014). Inquiry Journal 2014. http://www.unh.edu/ inquiryjournal/inquiryjournal/spring-2014/searching-opportunities

This Commentary is brought to you for free and open access by the Inquiry Journal at University of New Hampshire Scholars' Repository. It has been accepted for inclusion in Inquiry Journal 2014 by an authorized administrator of University of New Hampshire Scholars' Repository. For more information, please contact Scholarly.Communication@unh.edu. 


\title{
Inquiry Journal
}

\author{
Undergraduate Research Journal : Spring 2014
}

\section{Commentaries}

\section{Searching for Opportunities}

—Sasa Tang (Editor: Brigid C. Casellini)

Sasa Tang graduated from the University of New Hampshire in May 2011 with a degree in politcal science and international affairs.

In the summer of 2010, I conducted a three-month research project in Tanzania through the International Research Opportunities Program (IROP) to gather data for my senior thesis as an international affairs/political science major. My thesis was about aid effectiveness in development projects in Sub-Sahara Africa. I went to Tanzania to learn about aid organizations' views and perceptions of the effectiveness of their work and to understand their interaction and relationship with the Tanzanian government. I talked to policymakers and realized there was such a disconnect between those who were making the policies and those who were receiving the services from the policies.

My IROP experience felt like both the inspiration for and first draft to life in Morocco, where I am currently a Youth Development Peace Corps volunteer. I joined the Peace Corps because I really wanted to help people, and help them correctly. IROP taught me to open my eyes to the things I could learn by observing people's lives and, most importantly, to create opportunities for myself.

IROP was a two-part experience: the research proposal writing and the actual on the ground data collection. I thoroughly enjoyed the proposal writing because it was a familiar process, similar to writing research papers and structured with deadlines. I was overjoyed when my proposal got accepted and I remember clearly what Professor Ben Cole said to me following his congratulations, "Now you actually have to go to Tanzania and do your research." That was when it hit me. I had to go to Africa and spend three months there alone. Yikes.

In what felt like no time at all, I landed in the sticky, sweltering heat of Dar es Salaam, Tanzania. I was completely lost. Everything was new to me. The colors, smells, and sound of the language were all new; the way people carried their things on top of their heads was unfamiliar, and the way people stared at me was uncomfortable. I have never felt so independent and so alone in my life.

\section{Losing Control}


My three months there started out as a complete blank. I did have a foreign mentor with whom I met from time to time, but most of the work was up to me. For my research on aid effectiveness, I needed to find national and international organizations to interview. When I was back in the states preparing for this project, I had tried to use the internet to find organizations to interview, but I quickly realized that very few organizations had websites, and even if they did (because they were a branch of an international organization), their websites contained very little information and barely any contact information.

When I got on the ground, I learned how to do things the Tanzanian way. I would show up at an organization's office and ask directly to set up an interview with the country director or programs director. Sometimes I was lucky to get an interview in the same day, or sometimes I would have to go back three or four times before someone was available to meet with me. One interview, or one attempt, could take all day because it would take me hours to figure out the local transportation system and how to get there, hours to find the organization's building, and hours to find my way back. To fill my time even more between interviewing, researching, and transcribing, I volunteered at an organization helping to

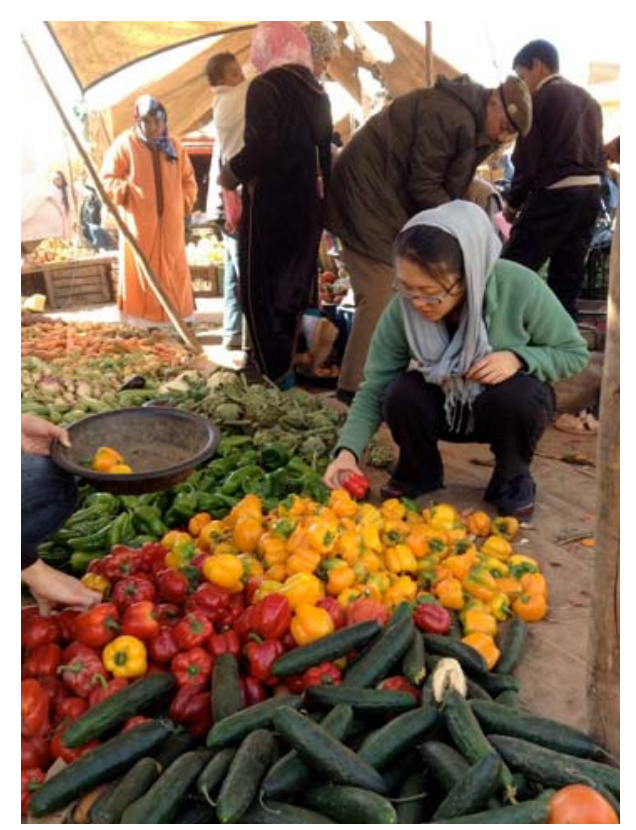

The author choosing vegetables at a street market in Ouaouizeght, Azilal Province, Morocco. develop a group of community health workers who could focus on nutrition education. For everything I did in Tanzania, I had to find my own opportunities. Unlike research in school, I didn't have anyone telling me what to do, how to do it, or by when to finish the work. Time and work in America are linear concepts, but in Africa, everything is fluid. People don't work according to the time; people work and plan according to what opportunities and chances life hands them.

Not only was work unstructured and unfamiliar to me in Tanzania, daily life was a challenge as well. Up until then, I had never lived alone. I remember vividly the first meal I made for myself: I went to some street vendors outside of the guesthouse where I was staying and bought two ears of corn on the cob, two eggs, and two carrots. I boiled a pot of water and put everything in at once. I remember standing in the kitchen, eating my over-boiled and cracked eggs and undercooked everything else, and crying. I didn't know how to cook, nor how to deal with red furry cockroaches, nor how to force myself to drink boiled water (in order to kill bacteria) in hundred-degree weather. I remember my first time washing my clothes by hand. I realized I didn't know what to do! I walked around my neighborhood and spied women who were doing it and learned from them.

I cried a lot in Tanzania. Every morning I had to put on courage just to leave the house, and at night I cried for the experience to be over. I was emotionally and physically exhausted; it was the hardest three months of my life. Until Peace Corps.

\section{Gaining Courage}

They say that Peace Corps is the hardest job that you will love. It's true. When Peace Corps volunteers arrive in a country, we get a three-month training period where we live with host families to learn the language (Moroccan Arabic) and the culture (Muslim). Once we arrive at our own separate sites, however, we are on our own. When I arrived at my site in Morocco, I found myself again directionless and without structure. I had to find my own 


\section{opportunities to create my own work.}

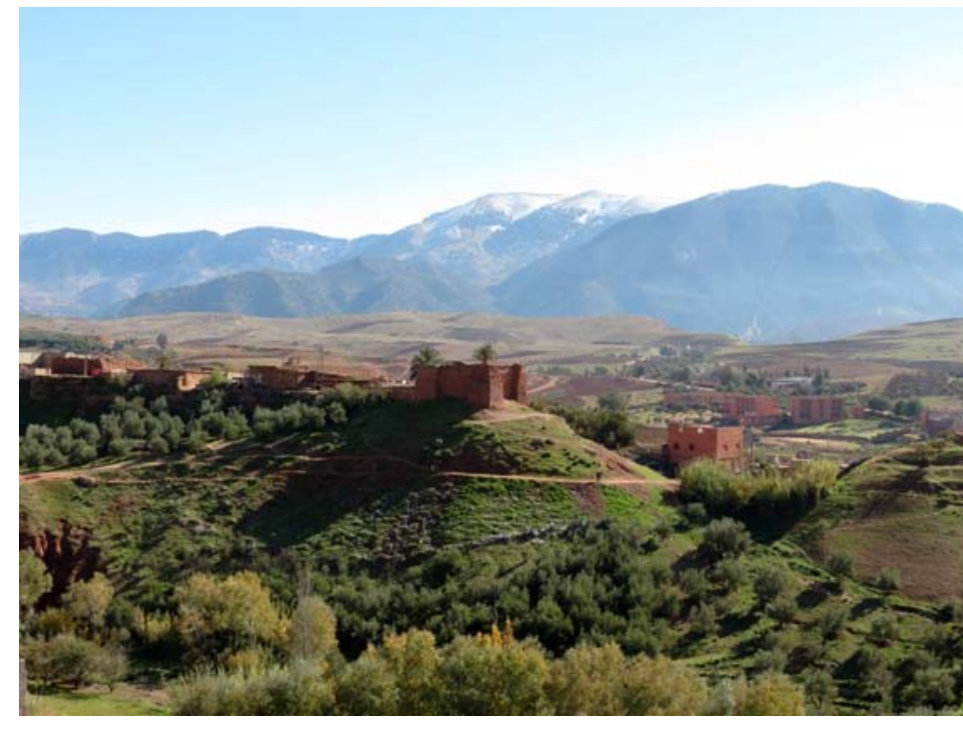

The view from the author's apartment in the village of Ouaouizeght, Morocco.
My site is a small mountain village about two miles high in altitude. When it rains or snows, the clouds cover my village and I cannot see the next house over. It's so mountainous that there is not enough flat land for even a soccer field. The main economy here is sheep, olives, walnuts, almonds, and fishing. (There is a sizable lake within walking distance.) In the summer it can get up to 130 degrees, and in the winter the water in my latrine freezes. In the winter I bucket bathe about once every week or every two weeks because it's too cold to take off my clothes. The population is about 10,000 , and even though it's small, it's the largest village within twenty-five miles in the surrounding mountains. I live alone in a studio apartment on the roof of a building. I spend most of my days with neighborhood women, knitting, drinking tea, cooking (they love cookies), and speaking to them in Arabic.

For the first couple months in site, Peace Corps volunteers conduct a community assessment in order to understand what our community has and what it needs. In my community, the culture for girls and women is pretty oppressive. Girls are not allowed outside after 6 p.m. (which is when school gets out), and women generally stay inside the house all day.

Currently I am working to empower girls through discussions and activities on self-image, confidence, finding a voice to fight street harassment, and by encouraging them to think differently about their future. Most of their mothers got married between the ages of thirteen and sixteen and are illiterate. Although most girls still aspire to get married and stay at home, I am hoping to show them other possibilities for their future.

I also work with older women on nutrition and exercising. I came across the opportunity to create such a group while having tea with some women who were laughing and complaining about having a big stomach and having no opportunity to work out to lose weight. Three or four times a week we wake up at 5:30 a.m. (right after the first call to prayer) and go to the youth center and work out privately from 6-7:30 doing aerobics. The women have to be home before 8 a.m. to make breakfast and send their husbands and children to work and school.

Through another conversation, I learned about a group of people who wished to start a juice vending business but had no business background. I then taught these people, both men and women who never finished high school, a course in basic economics. Everything that I do here in Morocco comes from seeing needs, and then reaching out and creating a group or a class to address these needs. Again, there is no structure-only me. The sense of taking life in my own hands, creating my schedule according to what life gives me, is something that my experience in Tanzania taught me.

In Tanzania I had felt a lot of "lacks" in life-lack of microwave, lack of washing machines, lack of internet, lack of 
friends, and so on. But here in Morocco these same "lacks" have changed into "opportunities to learn" how to create something from the origin. I see possibilities and chances instead of problems. I am learning how to cook and now know how to make things from scratch. I have made gnocchi and pumpkin pies. I've come a long way since my boiled eggs, corn, and carrot disaster. When I feel lonely, I go to a woman's house and we talk. When I want internet, I pick up a book and read, or I draw, or knit. Instead of the "conveniences" which my American life has given me, I now enjoy the simple things in life. Living so closely to life and so far away from machines is quite exciting.

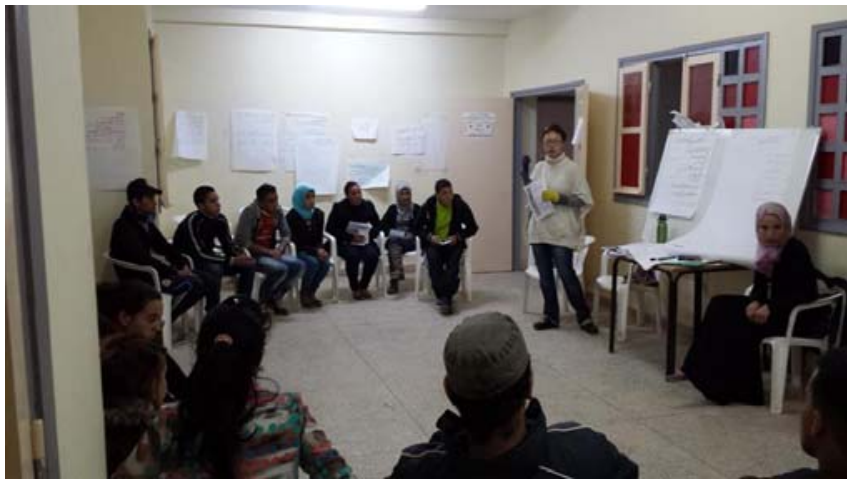

The author teaching a life skills class in Ouaouizeght.

I joined the Peace Corps because in Tanzania I realized

how important it was to me to be able to help people. One big reason for a disconnect between policymakers and those on the receiving end is that the policy makers do not understand the lives of those who they are trying to help. I want to understand their lives. I came to Morocco to live as one of them, to see what they see, to feel what they feel, to need what they need in order, one day, to truly fill their needs. Inshallah.

I would like to thank so many professors for my first research adventure abroad. I would like to thank Professor Georgeann Murphy for being so patient with me, helping me connect to others, and editing my papers. I would like to thank Professor Lawrence Reardon for guiding me. I would like to thank Professor Ben Cole for helping me keep my humor. I would like to thank Professor Joe Lugalla for opening Tanzania to me. And finally I want to thank my friends and family who have supported me in these two challenging and rewarding years of my Peace Corps service.

\section{Author bio}

As a current member of the Peace Corps in Morocco, University of New Hampshire alumna Sasa Tang ('11) is a veteran traveler now, but that was not always the case. In 2009, Sasa applied for an International Research Opportunities Program (IROP) grant to explore her interest in Nongovernmental Organizations (NGOs) while conducting research for her thesis in Tanzania. As a political science and international affairs major, Sasa was interested in experiencing another culture "on the ground." When the native of Lee, New Hampshire, arrived in her new African home, adjustment was difficult. Sasa felt unprepared for the living conditions in Tanzania and was quickly forced to learn a range of new skills, including living "on Africa time" and cooking meals, in order to thrive in her new location. Looking back on the experience, Sasa is proud of her ability to provide for herself independently. Although Sasa's focus has moved away from NGO work, she continues to be interested in international relations and in seeking new challenges. With encouragement from her former UNH adviser, she chose to submit a commentary to Inquiry and says that the writing process has boosted her self-confidence. Sasa recently got a job in Morocco which will allow her to continue working with women and girls in development once her Peace Corps commitment is over. She will stay in Morocco for one more year and take Arabic classes on the side.

Lawrence C. Reardon is an associate professor of political science and coordinator of the Asian studies minor at the 
University of New Hampshire. Dr. Reardon has taught at UNH since 1991, and specializes in Asian studies, international relations, and international political economy.

Dr. Reardon also mentored Inquiry authors Susannah Pratt (2007), Laura Smetana (2007), and Jennifer Lindsay (2014).

Contact the author $>>$

Top of Page $>>$

Copyright 2014, Sasa Tang 